\title{
GREEN BUSINESS EVENTS: PROFILING THROUGH A CASE STUDY
}

\section{BILL MERRILEES* \& KATHRYN MARLES**}

* Department of Marketing, Griffith Business School, Griffith University, Gold Coast campus, QLD, Australia.

** Department of Tourism, Leisure, Hotel and Sport Management, Griffith Business School, Griffith University, Gold Coast campus, QLD, Australia.

There is an ever increasing emphasis being placed on business in general to address not only issues of sustainability, and more specifically the issues associated with reducing the negative environmental outcomes of business activity. While some events incorporate environmental sustainability as a core part of their brand, there is less documented evidence that the strategies of 'reduce, reuse and recycle' have been adopted in the more 'mainstream' business events sector. This paper analyzes green practices of business events through a case study approach. The evidence suggests a green exhibition business event profile: an overarching environmental policy foundation, reusing materials through subcontracting and a comprehensive, costdriven set of green practices emphasizing energy conservation and waste minimization. The green practice mix of exhibition business events differs from other event types.

Keywords: Green events; business events; green practices; practice-mix.

Address correspondence to: Professor Bill Merrilees, Department of Marketing, Griffith Business School, Griffith University, Gold Coast campus, QLD 4222, Australia. Tel: +61 (0)7 5552-7176; Fax: 61 (0)7 5552-9039; E-mail: bill.merrilees@griffith.edu.au 


\section{Introduction}

Some events deliberately position themselves as green events (e.g. Byron Bay International East Coast Blues and Roots Festival in North East New South Wales; Woodford Folk Festival as a consumer orientated music festival in South East Queensland, Australia). However, the Business Events sector has been less responsive to this trend. Business events are rarely studied in terms of their green practices. The presumption may be that commercial and financial considerations dominate and therefore environmental considerations are secondary. The situation in practice is unknown because of the relatively few previous academic studies of green business events.

This paper explores the adoption of environmental policies and practices within a business event, and in particular examines a mature exhibition event that has been highly successful for more than twenty years. The research objective is to identify and evaluate the environmental policies and practices at a major Australian business event, namely the Sanctuary Cove International Boat Show. A case study method is employed. The evaluation of green practices is placed within a wider study of the marketing and economic impact of the Boat Show. A broader study objective is to put forward the full set of green practices at the Boat Show as a benchmark for other future green events, as a yardstick and motivator to match or even better in taking greater green action.

\section{Green Events}

Researchers have only recently studied environmental aspects of events in earnest. A 2001 review of the event research literature found that less one per cent was 
devoted to environmental issues (Harris et al. 2001). In terms of publications, 2010 seems a peak year.

What is meant by green events? There is no consensus on this issue. Getz (2009) prefers to integrate environmental aspects with the broader sustainability components of social, cultural, economic and environmental roles. He sees green events as part of the sustainability equation and includes the familiar reduce, re-use and recycle, combined with the additional need to reduce energy consumption associated with tourism. Laing and Frost (2010) define a green event as one that has a sustainability policy or incorporates sustainability practices into its management and operations. These authors thus suggest that green events often (italics added) have broader concerns than their environmental impact. There is thus a high degree of consistency in the definitions by Getz (2009) and Laing and Frost (2010) and with other related papers (Presbury \& Edwards, 2005). However, the italicizing of "often” suggests a degree of ambiguity in the Laing and Frost (2010) definition of green events.

A simple alternative definition is a slight variation of the Laing and Frost (2010) definition: A green event is one that incorporates environmental management practices into its operations. This definition replaces the term "sustainability" with the term "environmental", and is the definition used in the current paper. A close cousin of this term is an event adaption from the hotel definition in Jackson (2010), namely: A green event represents the concerted and deliberate efforts and practices by event managers and their agents to mitigate, ameliorate and eliminate the negative impacts of events on the environment.

In the literature, definitions of green events by Laing and Frost (2010) and others seem to use the term green event in a generic sense, meaning any effort to incorporate environmental management matters, rather than provide exemplar cases, that are very 
green. Perhaps a better term for general environmental action to improve the environmental impact of events might be called greening (implying a change rather than an absolute standard). Notwithstanding, the paper continues with the tradition of using the general practice of describing such activities as green events, but advising any event against calling itself green unless it reaches a high, exemplary level of greenness.

\section{Literature Review}

Most of the initial literature is discussed in general terms but usually in the context of hospitality and tourism, where most of the event-related studies of greening occur. The more explicit literature on green business events is much smaller and follows as a subsequent section.

\section{Motivations}

The motivation to adopt or not to adopt environmental practices within business operations falls into two main categories, namely ethical or commercial considerations (Sharma, 2000). The ethical considerations of managers act as a driver for adopting environmental practices (Bansal \& Roth, 2000; Lynes \& Dredge, 2006; Park \& Boo, 2010; Revilla, Dodd \& Hoover, 2001). The internal leadership within organizations (Lynes \& Dredge, 2006) combined with championing behaviors of managers (Andersson \& Bateman, 2000) sets the groundwork for the adoption of environmental practices within organizations. As well, various researchers have identified managerial attitudes and norms as barriers to adopting green business 
strategies (Marshall, Cordano \& Silverman, 2005; Bohdanowicz, 2005; Mair \& Jago, 2010; McBoyle, 1996).

The commercial benefits include the reduction in operating costs and the marketing leverage that can be made from such policies (Tzschentke, Kirk, \& Lynch, 2004). While some researchers have argued that the claims of financial gains are limited, they have also recognized the commercial value in adopting environmental practices. Claver-Cortes, Molina-Azorin, Pereira-Moliner \& Lopez-Gamero (2007) found that while there was little evidence of an increase in financial performance there was evidence of increases in other business performance levels as the proactivity in adopting environmental philosophies increased. Gilley, Worrell, Davidson \& ElJelly, (2000) found that there was a positive impact on the reputation of the organization although there was no real effect on the stock returns.

Within the Hospitality sector, many large hotels have found that it is less expensive to reduce waste (e.g. soap dispensers instead of individual soap sachets), reuse waste (e.g. grey water for the gardens), and recycle waste (e.g. plastic, paper and vegetable waste) (Iwanowski \& Rushmore, 1994; Wight, 1994). In other words, 'it pays to be green'. Sharma (2000) observes that common industry sectors tend to adopt similar environmental strategies. An excellent study of the business case for hotels to go green is Graci and Dodds (2008) who emphasize the benefits of cost savings, brand image enhancement, employee loyalty and customer retention, as well as greater ease of regulatory compliance and better risk management.

Small organizations can find it difficult to ‘go green’ (Bohdanowicz, 2005; Tilley, 1999), as the economies of scale do not advantage the small operation. The managerial attitudes are constrained by the financial costs associated with adopting environmental practices and are a barrier to adoption (Revilla, Dodd \& Hoover, 2001; 
Tzschentke, Kirk, \& Lynch, 2004). Small operators report a divide between the aspirations of managers and the practices employed. This argument is countered by because environmental practices are being employed regardless of the corporate motivation, and further suggesting that managerial ethical considerations are drivers for adoption of environmental practices.

Regulatory involvement of governments and trade associations also act as motivational drivers for adopting environmental policies and practices. The motivational issue then becomes one of conformity versus voluntariness and the business and operational decision-making among managers is more reactive than proactive (Ayuso, 2007; Dickson \& Arcodia, 2010; Font, 2002; McNamara \& Gibson, 2008; Marshall, Cordano \& Silverman, 2005; Revilla, Dodd \& Hoover, 2001; Sharma, 2000). The impetus for adopting environmental policies and practices is therefore driven primarily by the desire for accreditation from professional bodies and pressures to conform to legal requirements and industry codes of conduct, rather than any real sense of ethical responsibility among managers. The criticism has been made that such corporations are merely 'jumping on the green bandwagon' as the primary motivation comes in response from legal pressures and financial incentives.

The adoption of environmental policies and practices has also partly occurred in response to the increasing public awareness and concern of environmental issues. Research suggests that a similar divide exists among tourists as was found among managers. That is, the aspirations of tourists are not always reflected in their behavior (Bergin-Seers, 2009; Han, Hsu, \& Sheu, 2010). While many consumers feel a sense of environmental responsibility and satisfaction with sustainability practices, some consumers are clearly more dedicated to environmental causes and tend to display higher levels of environmental awareness and practice within their home lives as well 
as when they are tourists (Andereck, 2009; Bergin-Seers, 2009; Lawton \& Weaver, 2010). Conflict occurs over the issue of where the responsibility is for implementing environmental practices and policies (Blackstock, White, McCrum, Scott \& Hunter, 2008; Dodds, Graci \& Holmes, 2010).

A final perspective about the management approach to event environmental management comes from Porter and Kramer (2006). Their paper is not about events and has a broader concern, namely corporate social responsibility. These authors argue that much of the debate about corporate social responsibility (CSR) is posed as a competition between business and society. Rather than simply adding on CSR as a do-good action, it is more constructive to recognize the inter-dependence between the two and integrate CSR activities into the operation of the company.

\section{Business Events}

Researchers recognize business events as high yield tourism activities and the economic contributions are well documented (Deery, Jago, Fredline, \& Dwyer, 2005); however little research has been conducted on the environmental impacts of these events. There seem to be only two explicit studies of green business events, namely Park and Boo (2010) and Mair and Jago (2010).

Park and Boo (2010) study green attitudes associated with two USA conventions, mainly from the perspective of the convention attendees but also from the viewpoints of the meeting planners and the convention suppliers. The study emphasizes the attitudes that these stakeholders have. The dominant environmental issue across the three stakeholders groups is the high environmental waste associated with travel, particularly international air travel. Other concerns are energy waste, food and beverage waste, and solid waste. Stakeholders show a moderate concern for 
environmental issues, but are reluctant to pay extra for environmental improvement. Among suppliers, recycling and energy waste management were the most utilized environmental practices, but the evidence is presented in a poor way. Carbon offsets were rarely practiced and there was low awareness of green certifications.

Mair and Jago (2010) develop a conceptual model of greening in the business event sector. The emphasis of the model is on the drivers of and barriers to greening practices. Their model begins with organizational objectives and values, in an economic context, guiding drivers (benefits) and barriers (such as regulations) and further facilitated by media, culture and eco-champions, ending with different degrees of green practice. Ten interviews helped shape the model for the convention industry (executives from visitor bureaus, convention centers and industry associations). Their results indicate an industry in an embryonic stage of greening. Much of the development occurring seems to be allied to the need to "be seen to be green" and to be connected to an individual company's own CSR and related policies. Ecochampions seemed important. Compared to other sectors, business events seem to downplay financial benefits of greening, the role of stakeholders and of regulations.

Each of the existing studies focus on the convention sub-sector of business events. Both studies indicate that greening is an emerging issue in business events, not fully embraced by the sector, but with positive interest gaining momentum. In terms of details, it is difficult to compare the findings as they have different scope. However, there is some suggestion that business events are different to other events, but certainly with a major concern about the cost of being green.

The current study takes these two studies as a point of departure. The focus is on a different sub-sector of business events, namely exhibitions/trade shows, for which there are no previous greening studies. The current study is also different in the sense 
that it a study of a particular business event (Sanctuary Cove Boat Show), rather than a sector or industry perspective. An individual event study enables the closer examination of nuances. It leads to different conclusions to those of Mair and Jago (2010), partly because of the ability to discern nuances and partly because of differences between conventions and exhibitions as business events.

\section{Sanctuary Cove International Boat Show}

The business event literature has predominantly concentrated on the Conference and Convention sector and less attention has been directed towards other business events, specifically exhibitions. Exhibition events, such as the one discussed in this case study derive from the culmination of operations of several stakeholder groups, namely venues, exhibitors, suppliers, sponsors and attendees. Therefore, attempts by the event managers to adopt environmental policies and practices are complicated by the motivations and actions of each of the stakeholder groups and even further by the location of its setting and the numerous stakeholders some of whom permanently reside in the setting.

The Boat Show is held annually at Sanctuary Cove, that is an integrated resort situated at the north end of Australia's Gold Coast., and which consists of residential properties, a five star Hyatt Regency Resort, a Country Club, a Marine Village with over 90 retail outlets and restaurants, two golf courses and four marine harbors. A tourist attraction in its own right, it is open to the public and attracts several million visitors a year.

The Sanctuary Cove International Boat Show is a highly successful and mature business event that has been operating at the current location for more than twenty 
years. It has an international reputation and is recognized as the largest on-water display of boats in the Asia Pacific region. It attracts buying delegations from around the world and marine executives from Asia, USA and Europe attend the show to support dealers and importers. The Sanctuary Cove International Boat Show’s slogan "Where the Marine Business Does Business" highlights the importance of the business side of the event. The Boat Show contributes a significant economic impact to the destination as well as to the general marine industry.

In 2008, there were a total of 45 suppliers, 3 major sponsors, 455 exhibitors, and just over 390 boats displayed on the water. Approximately $40 \%$ of exhibits were housed in the four temporary pavilions, $30 \%$ in the open area hardstands that are situated throughout the Marine Village, and 30\% in eight marinas, of which four are temporary and purpose built for the Boat Show.

\section{Methodology}

A case study method was designed to investigate the green practices of the Sanctuary Cove International Boat Show (Creswell, 1994; Patton, 2002; Yin, 2004). The focus of this study was to explore the management approach to adopting environmental policies and practices. Data collection and analysis drew on the content of various company documents, including the Web Site, Exhibitor application Procedures, the 2008 Yearbook (164 pages) and an internal PowerPoint presentation to other stakeholders by Management. Additionally, the researchers explored with the project management team of the Sanctuary Cove International Boat Show, their environmental policies and the specific environmental practices they employed in organizing and running the event. The management team consisted of six key 
personnel; General Manager, Assistant General Manager, Administration Manager, Operations Coordinator, Event Manager, and Public Relations and Media Manager. Both the General Manager and the Event Manager were members of the original management team, and had presided over the inception and growth of the event for the past twenty years.

Initially a questionnaire was mailed to the management team; using this information as a catalyst, the researchers conducted semi-structured in-depth interviews with the management staff responsible for environmental policies and practices. The duration of the interviews varied. Several one hour interviews were held with the Event Manager. Interviews with the other staff were relatively short, usually 10-20 minutes. Information pertaining to the environmental policies and practices was sought, and evidence of formal mechanisms to implement environmental practices was provided, including policy documents. These were then qualitatively analyzed using content analysis techniques. The broader marketing and economic evaluations were assessed using quantitative surveys and will only be reported here in very general terms.

\section{Results}

In terms of patron, exhibitor and supplier feedback across all features of the event, the Boat Show is rated very highly by more than 90 percent of the respondents. The Show Team identified that they were well organized and service oriented and that their communication and relationships with exhibitors and supplier businesses were extremely good. In essence, the staff acknowledges that they preside over a very successful event. Among their self-reported highest qualities were their 
communication and willingness to go 'above and beyond' in terms of service. The marketing and economic impact evaluation confirmed what most observers believed, that this is a very successful and enduring event.

The researchers evaluated the position of green policies in the overall business strategy, before detailing the specific environmental practices at the Boat Show. The formal presentation of the company, in terms of the Yearbook, Web site and internal PowerPoint communications make minimal reference to environmental matters. As expected with most business events, green aspects are subservient to marketing and economic considerations. The Boat Show event is presented to maximize satisfaction among patrons and exhibitors. The event is definitely not presented as a specific "green event", nor even is there much public emphasis on it being "an environmentally-friendly event”. The researchers found no major formal environmental policy or strategy. Thus, there is no pretence in the form of green washing. However, the event does engage in quite a number of green practices, which do deserve recognition and which can to be coded, classified and documented and compared to other events. Specific environmental practices can be grouped under various categories of environmental practices.

\section{Environmental Practices of the 2008 Sanctuary Cove Boat Show}

\section{Planning and Policies}

As explained, there is no major formal environmental policy. More generally and perhaps indicative of long-term intent, Sanctuary Cove marina is a member of the Marina Industries Association of Australia. The marina is working towards the Meetings \& Events Australia (MEA, 2010) Clean Marinas program to reduce its 
carbon footprint with an aim eventually to achieve zero impact on the environment. The zero impact aim, as identified by the researchers, is aspirational and without a time-frame. Business Events Australia (BEA) Green Check-list and the MEA Green Events Checklist were developed as support for members. Both checklist guides are similar and were helpful to an extent to organizations like Sanctuary Cove Boat Show in developing their environmental policies and practices.

More specifically and as part of its procedures, Sanctuary Cove Boat Show key services, such as waste, exhibition fit-out and construction, are carried out by contractors. Environmental practices of the contractors are considered during tendering. The event management did conduct a broad green audit, but without specifically measuring the carbon footprint of the event. However, they did document a number of environmental practices used, as follows.

\section{Recycling}

Recycling bins were extensively available. However, observations by the researchers suggest there is nothing exceptional in the scale of the recycling activities, which were mainly confined to the outdoor areas.

\section{Reuse}

Rather than invest in expensive equipment and infrastructure, such as pontoons, buildings, and tents, which would otherwise be unused for much of the year, the Boat Show subcontracts these services to specialized firms. The firms in essence "reuse" the equipment more frequently by renting them to other events. The reuse is therefore indirect and perhaps invisible, but nonetheless an environmental solution. 


\section{Reduce Waste}

A number of activities saved paper (and time) by the use of electronic mechanisms, including:

- Online exhibition site maps and exhibition terms allowed exhibitors to view information without wasting paper

- Where possible all exhibitor correspondence was carried out by email to reduce paper use

- Online ticketing and accommodation booking saved the use of paper. Innovations in 2008 led to a 69\% increase in May 2008 website click-throughs compared to 2007. In May alone there were more than 25,200 visits

- Tax invoices were sent via email delivery, saving paper

- Press releases and correspondence with media were online, saving paper, and the releases were downloadable from the website.

Complementing electronic interaction was the creation of the Yearbook as a DVD, saving paper for international and domestic marketing post-event marketing in the lead up to the next year's Show.

\section{Reduce Energy Consumption}

With no general public visitor parking on site, the Show minimized carbon emissions by offering streamlined "park 'n' ride” and bulk-transport options for visitors. Visitors attended the Show by ferry, bus, train with shuttle connections, or by parking at Parklands, where the local council maintains a major public car parking area, with a connecting return shuttle bus. Additional measures taken include an electrical audit conducted by independent contractors who made adjustments to the grid coverage with estimated savings of $15 \%$ in usage. 
Reduce environmental damage and negative community impact

Plastic show bags and balloons were banned by Boat Show management in 2007 and that ban was repeated in 2008 to reduce the environmental impact and potential for polluting Gold Coast waterways. Additionally, a post-event land site inspection was carried out to assess any damage to landscaping to effect quick repairs.

In terms of reducing negative community impacts, the nearby residential community is partly managed by the same property group as the event. Therefore, the interests of the nearby residents are factored into the planning for the Boat Show. In part, this aspect influenced the motivation for the "park 'n' ride” public transportation model. Further, in terms of avoiding excessive water consumption, Boat Show exhibitors were advised in advance of city water restrictions and staff policed the use of water by exhibitors to ensure compliance with the Level 5 water use limitations. Finally, in terms of social benefits, it is important to note that a number of stakeholder groups were surveyed, including patrons, exhibitors, suppliers and event management employees. All of the evaluations were positive, suggesting considerable social benefits of the event, consistent with findings for other business events (Getz, 2009; Laing and Frost, 2010).

\section{Integrating environmental management into normal operations}

Following Porter and Kramer (2006), it is clear that the feature of integrating environmental management into normal operations is quite strong. Environmental issues are considered as part of the tendering process for contractors. A wide range of communications use electronic mechanisms as standard. The considerable use of public transport through the “park 'n' ride” scheme is now institutionalized as a 
normal routine, expected by all stakeholders. All of these matters are now seen as the normal way to do business, without overt fanfare that something special is being done for the environment. Although there is scope for more work, to a degree the Boat show has reached the ideal state advocated by Porter and Kramer (2006).

\section{Evaluation of the Boat Show Green Practices}

The above categories of environmental practices are consistent with the classic environmental trilogy of reduce, recycle and reuse. The MEA hints for green event practice follow similar headings, with planning and policies added, which helps set the broader policy agenda for such practices. The researchers have split reduced resource use into the two sub-types: reduced waste and reduced energy consumption. Further, based on the environmental literature, another category is added: reduced environmental damage and reduced negative community impact. These categories help to assess the nature and extent of green event practices.

It should be pointed out that the categorization of the environmental practices is researcher-based. The event management team perceives the environmental practices as a total block, rather than in discrete categories.

The first impression of the list of environmental practices associated with the 2008 Boat Show is that it is a perhaps surprisingly long list. The event undertakes a considerable number of environmental practices. Secondly, it is clear that all of the categories have some practices represented within; there are no empty categories. Thus, the environmental practices can be termed comprehensive, rather than narrowly based. Thirdly, most practices are engrained into the processes of the organization, starting with long-term goals, a reuse principle through subcontracting, and further 
operationalized through sensitive tendering, communications and transportation procedures. As such, it would be relatively easy to sustain such green practices. Fourthly, in terms of the priorities in the green program, reduced energy consumption has the biggest quantitative carbon footprint benefit, based on the transportation and electrical grid adjustments. Reduced waste through electronic mechanisms was the most numerous practice, though with less significant footprint benefits. Recycling is perhaps the lowest rating of all environmental practices.

Based on these four assessments the researchers judge the 2008 Boat Show green practices as positive. It certainly does not reach the absolute heights of being a "green event” or "an environmentally-friendly event”, but it would seem to rate as at least average in terms of how green the business event is. Below, the findings are compared firstly with a different type of business event, namely conventions and secondly with consumer events, in the form of birding festivals.

Although caution is needed because only one exhibition business event has been studied, the Sanctuary Cove Boat Show represents a constructive case example of how to introduce green practices into an exhibition business event. A comprehensive set of green practices is suggested, with a broad but informal plan, maximizing re-use through subcontracting key supply services and emphasizing energy conservation and waste reduction.

\section{Comparison of Two Types of Business Events}

Although there is limited evidence for all types of business events in terms of greening, the current results for exhibition/trade show business events can be compared with conventions in terms of greening. The two recent papers by Park and Boo (2010) and Mair and Jago (2010) both indicate a concern for the financial costs 
and the lack of financial benefits of greening practices in the case of conventions, with no such concerns in the current (exhibition) study. In fact, the Boat Show case indicates considerable financial benefits through energy savings and lower paper consumption, and thus closer in spirit to the environmental approach in the hotel industry, as noted by Graci and Dodds (2010). Part of the reason for the inter-business event difference is the difficulty of appropriating benefits of greening via energy savings at conventions, when the location of the convention varies from year to year and the industry association hosting the convention does not actively manage the property asset. One practice that the convention host can actively influence is recycling of leaflets and beverage containers, and it is not surprising that recycling is the major green practice identified by Park and Boo (2010). Conventions generate a lot of recyclable waste creating a major opportunity for this type of green practice. In contrast, the exhibition type business event such as the Boat Show has a short duration per patron impact (hours compared to days at a convention) and fewer meal and drink breaks, a high outdoor component, and in total less opportunity for generating recyclable waste, though there is certainly potential to improve.

Three areas that appear broadly similar across the two types of business events in the greening context, comparing the current study with Mair and Jago (2010) include the considerable potential and important role of an eco-champion, the strong link to company's own CSR programs and the limited role of stakeholder influence. Certainly the Boat Show had an eco-champion (the Event Manager), though more evidence with other trade shows is needed to see how generalizable this aspect is.

The observation by Mair and Jago (2010) about the Australian convention industry greening practices being linked to company's own CSR programs was presented as a mixed blessing, partly good but partly neutral in terms of certain 
companies simply "wanting to be seen to be green". The Boat show practices were not explicitly linked to a CSR program, but were linked to their regular operational practices. Such practices included energy-saving measures, but also built into procedures of online site maps, online ticketing and online tax invoice issuing, among many other tactics, including considering the environmental practices of contractors in the tendering process. In total, the number of ways that environmental aspects are incorporated seamlessly into the operational procedures is impressive and an advance on the possible green washing which is associated with a perceived "to be seen to be green”. Most of the Boat Show green measures are made without fanfare and are simply part of doing good business. In this respect at least, the green credentials of the Boat Show could place them in the top third ranking of green business events.

The finding by Mair and Jago (2010) that stakeholder influences, especially pressure groups, had a minimal role for convention greening practices, seems to apply to the Boat Show. However, a possible exception is the role of industry associations, noted by Dickson and Arcodia (2010) as at least a moderate force. In the Boat Show case, various industry associations, including the Marina Industries Association, Meetings and Events Australia and Business Events Australia have collectively provided guidance and inspiration to the Boat Show. The industry associations have to be acknowledged in such a role. Notwithstanding, the industry associations are merely advisory, not regulatory and it is up to individual organizations whether they follow any advice and to what extent.

A different approach to stakeholder consideration is to shift from a focus of pressure group stakeholder influence to economic stakeholders which are part of the value chain generated by organizations. The emphasis on economically relevant stakeholders in a sporting event context is discussed in Merrilees, Getz and O’Brien 
(2005). Economic stakeholders need to be managed because they directly impact economic value generated. The Merrilees, Getz and O’Brien (2005) paper can be extended to include the impact of managing economic partners in generating green value. Exhibition/trade show managers or convention managers are in a prime position to be leaders in an economic network that generates both economic and green value. The Boat Show is well situated to monitor and alter key services, including waste, exhibition fit-out and construction, carried out by contractors. The Boat Show also exerts some control over the exhibitors in terms of how they conduct their business at the event. Event managers have a lead role to play and should take overall responsibility for both economic and green value. The Sanctuary Cove Boat Show management has taken some initiatives already in this respect. Other business event managers could match or better such initiatives.

\section{Comparison of an Exhibition Business Event with Birding Festivals}

In terms of other types of events, there are few examples of similar assessments of green practices. Laing and Frost (2010) do usefully highlight the role of identifying operational benchmarks of green practices, but only give selective examples rather than a comprehensive set of indicators. The most notable exception is Lawton and Weaver (2010) in terms of birding festivals. The choice of comparing a Boat Show with a birding festival may seem odd. The specific objective is to compare an exhibition business event with a number of consumer events, as part of a technique for comparing and contrasting green practices across business and consumer events and underlining their essential green features. As it happens, the birding festival is one 
of the best documented and so there is limited choice as to choosing which consumer events to represent.

It would be expected that birding festivals, by their nature, would be more environmentally-friendly. However, comparing the Boat Show's green practices with the frequency counts in Lawton and Weaver (2010) is a useful reference point. Re-use of signage and banners dominate (with 90 percent participation) the birding festival green practices. Re-use is less dominant in the Boat Show, though the use of renting rather than buying fixtures is important. Recycling (with 75 percent participation) was the second most popular green practice category at birding festivals. Again, recycling is clearly evident at the Boat Show, though not strong. Energy conservation (with 40 percent participation) was a distant third most popular category at birding festivals. In contrast, energy conservation was the dominant category at the Boat Show. Waste minimization, excluding re-use, was minimal at the birding festivals, though it was the second most important category at the Boat Show. Three additional categories, namely Environmental Planning and Policies, Reduce Both Environmental Damage and Negative Community Impact and Integrate Environmental Management into Normal Operations were present as Boat Show practices but not surveyed in Lawton and Weaver (2010). In broad terms, the comparison of the Boat Show green practices with the birding festival benchmarks reinforces the 2008 Boat Show green practices positive rating.

In summary, the different mix of greening practices between the Boat Show and birding festivals is noteworthy and explicable in terms of the nature and motives of the two types of events. The greater emphasis on reusing (for budget reasons) and recycling (for visibility reasons) at birding festivals makes sense, as does the greater emphasis on energy conservation and waste reduction for business events. Electrical 
audits make more sense for business events given their exhibition nature and scale. Similarly, waste reduction by using electronic rather than paper communications makes more sense for business events with say five or six regular staff at the event management headquarters. Cost reduction in particular and perhaps environmental compliance to a lesser degree, explains the use of green practices at exhibition business events, for all practices except recycling. However, even recycling bins are probably cost saving compared to the alternative costs of massive and labor-intensive cleaning up without bins and the health risks to patrons and exhibitors.

\section{Discussion and Conclusions}

The limited previous research on business events, especially exhibition-based ones, has been redressed as a beginning. By default the case study of the Sanctuary Cove Boat Show becomes a benchmark for green exhibition business events. However, the assessment of the green credentials of the Boat Show is positive and achieves at least an average rating; that is, it is much more than simply the first and only exhibition business event to be green evaluated. There are certainly areas for potential improvement, with the Web site needing more attention like most organizations, but at least the bar is set for the judging of other exhibition business events.

The case study findings yield three major environmental policy and practice implications. Firstly, the case study becomes a benchmark for other exhibition and other business events to match or improve on. Any exhibition business event wishing to aspire to average or higher green-friendly status has a specific target to aim for. Secondly, the case study puts green exhibition business events on the map for the first 
time. Business events are the most financially driven of all events and therefore potentially the most resistant to changing processes that improve the environment, but may risk profits. The findings show that considerable environmental-friendly progress can be made, to the benefit rather than at the expense of profits. Thirdly, government bodies like Tourism Australia and event associations like BEA and MEA, have responsibility and motivation to make events more environmentally responsible. However, they rely on information-sharing methods, such as web sites with hints for making events green. While these green events hints are useful to an extent, it is more effective to give specific, actual examples of the types of green practices actually conducted at an event, to have a greater impact. That is a benefit of the current case study. Evidence of real green practices actually used at a real business event are more effective than generic checklists, as an advice dissemination or promotional tool for policy bodies striving to reduce the environmental impact of business events.

To elaborate on these three major implications, benchmarks have a role to play in the environmental challenge. Environmental writers argue the ideal of setting targets, but equally acknowledge the difficulty or cost of actually measuring environmental impact, such as carbon footprint (Getz, 2009). Relatively few studies of green events actually measure environmental-friendly practices, with the most notable exception being Lawton and Weaver (2010). Rather than measure total environmental benefit it seems sufficient in the short and medium terms to simply list a set of environmentally beneficial practices, as Lawton and Weaver (2010) have. The current study follows this new approach, extending it to exhibition-based business events. All events could potentially list the environmentally beneficial practices that they use. Measuring environmental activities becomes a simple and easy means to use Key Performance Indicators (KPI), and motivates and facilitates event managers to make progress, 
either internally or more ambitiously externally in the wider event industry community.

Currently, two types of events dominate the green event debate. Sporting events, particular major events like the Football World Cup or the Olympics have attracted mainly negative academic critique, partly because of the event scale and the associated long-haul travel (Timsheva, 2001). A second set of events are softer in terms of potential environmental damage and have a natural affinity for the environment, such as birding festivals (Lawton and Weaver, 2010). Business events, in terms of their greenness, are relatively rare in academic studies. A presumption may be that the very strong commercial and financial rationale of business events makes them unlikely early adopters of green practices. The current case study of the Sanctuary Cove Boat Show counteracts that presumption. On the contrary, nearly all of the green practices adopted by the 2008 Boat Show were cost saving activities.

The third area of consequence of the current case study is in terms providing event associations, such as BEA and MEA, with case study material to illustrate their more generic lists, especially when the lists have been criticized for not adequately distinguishing between different types of events (Dickson and Arcodia, 2010). A key finding in the current study is that, in terms of greening practice mix, convention events differ from exhibition events and business events differ from consumer events. It is evident that a number of event associations are keen to improve their role in environmental practices. The Exhibition and Events Association of Australia (EEAA) was approached about to the information and advice that they provide for their members regarding environmental impacts, policies and practices of exhibitions. EEAA advised that they are currently in the process of developing their 
environmental policy and strategies for members, however the process is incomplete and they direct members to various other reference points.

\section{A Challenge for the Future of Green Business Events}

The event associations are striving to increase their environmental policy position. More generally it will be useful to have more academic green practice evaluations of business events. Such evaluations will make the environmental issue more prominent, and add additional insights and ideas.

In terms of events like the Sanctuary Cove Boat Show there is always scope for continuous environmental practice improvement, with Website development singled out in the feedback from stakeholders and recycling also needing more attention.

An interesting and potentially powerful future initiative for any business event manager is to take environmental management to a higher level through integrated stakeholder management of green practices. Many business events outsource key services, such as waste, exhibition fit-out and construction. Consequently, even though the environmental policies of the contractors can be scrutinized during the tendering process, the event managers may have limited effective control over the actual practices of the subcontractors. Event managers could take a lead role spearheading a collaborative, multi-stakeholder approach to environmental practice, creating more integrated solutions.

\section{Acknowledgements}


We would like to thank the Sanctuary Cove International Boat Show for their support financially in funding the research as well as their co-operation in helping access staff, patrons, exhibitors and suppliers for the event. Special thanks to Mark Jensen, then Assistant General Manager of the Boat Show.

\section{References}

Andereck, K.L. (2009). Tourists' perceptions of environmentally responsible innovations at tourism businesses. Journal of Sustainable Tourism, 17(4), 489-499.

Andersson, L.M., \& Bateman, T.S. (2000). Individual environmental initiative: championing natural environmental issues in U.S. business organizations. Academy of Management, 43(4), 548-570.

Ayuso, S. (2007). Comparing voluntary policy instruments for sustainable tourism: the experience of the Spanish hotel sector. Journal of Sustainable Tourism, 15(2), 144-159.

Bansal, P., \& Roth, K. (2000). Why companies go green: a model of ecological responsiveness. Academy of Management, 43(4), 717-736.

Bergin-Seers, S. (2009). Emerging green tourists in Australia: Their behaviours and attitudes. Tourism and Hospitality Research, 9(2), 109-119. 
Blackstock, K.L., White, V., McCrum, G., Scott, A., \& Hunter, C. (2008). Measuring responsibility: An appraisal of a Scottish National Park's sustainable tourism indicators. Journal of Sustainable Tourism, 16(3), 276-297.

Bohdanowicz, P. (2005). European Hoteliers’ Environmental attitudes: greening the business. Cornell Hotel and Restaurant Administration Quarterly, 46(2), 188-204.

Business Events Australia, (2010). Green Check-list.

http://businessevents.australia.com/Files/GREEN_CHECK-LIST_fact_sheet.pdf.

Viewed June, 2010.

Claver-Cortes, E., Molina-Azorin, J.F., Pereira-Moliner, J., \& Lopez-Gamero, M.D. (2007). Environmental strategies and their impact on hotel performance. Journal of Sustainable Tourism, 1(6), 663-679.

Creswell, J.W. (1994). Research design: qualitative and quantitative approaches. Thousand Oaks: Sage.

Deery, M., Jago, L., Fredline, E., \& Dwyer, L. (2005). National business events study. Common Ground, Altona Victoria.

Dickson, C., \& Arcodia, C. (2010). Promoting sustainable event practice: The role of professional associations. International Journal of Hospitality Management, 29(2), 236-244. 
Dodds, R., Graci, S.R., \& Holmes, M. (2010). Does the tourist care? A comparison of tourists in Koh Phi Phi, Thailand and Gili Trawangan, Indonesia. Journal of Sustainable Tourism, 18(2), 207-222.

Font, X. (2002). Environmental certification in tourism and hospitality: Progress, process and prospects. Tourism Management, 23(3), 197-205.

Getz, D. (2009). Policy for sustainable and responsible festivals and events: institutionalization of a new paradigm. Journal of Policy Research in Tourism, Leisure and Events, 1(1), 61-78.

Gilley, K.M., Worrell, D.L., Davidson, W.N., \& El-Jelly, A. (2000). Corporate environmental initiatives and anticipated firm performance: the differential of process-driven versus product-driven greening initiatives. Journal of Management, 26(6), 1199-1216.

Graci, S., \& Dodds, R. (2008). Why go green? The business case for environmental commitment in the Canadian hotel industry. Anatolia: An International Journal of Tourism and Hospitality Research, 19(2), 251-270.

Han, H., Hsu, L., \& Sheu, C. (2010), Application of the theory of planned behaviour to green hotel choice: testing the effect of environmental friendly activities. Tourism Management, 31(3), 325-334. 
Harris, B., Jago, L., Allen, J. \& Huyskens, M. (2001). Towards an Australian event research agenda: first steps. Event Management, 6(4), 213-221.

Iwanowski, K., \& Rushmore, C. (1994). Introducing the eco-friendly hotel: there are lots of reasons to pay attention to eco-tourism and, let's face it, the main ones have to do with money. Cornell Hotel and Restaurant Administration Quarterly, 35, 34-38.

Jackson, L. (2010). Toward a framework for the components of green lodging. Journal of Retail \& Leisure Property, 9(3), 211-230.

Laing, J. \& Frost, W. (2010). How green was my festival: Exploring challenges and opportunities associated with staging events. International Journal of Hospitality Management, 29(2), 261-267.

Lawton, L. J., \& Weaver, D.B. (2010). Normative and innovative sustainable resource management at birding festivals. Tourism Management, 31(4), 527-536.

Lynes, J.K., \& Dredge, D. (2006). Going green: motivations for environmental; commitment ion the airline industry. A case study of Scandinavian Airlines. Journal of Sustainable Tourism, 14(2), 116-138.

McBoyle, G. (1996). Green tourism and Scottish distilleries. Tourism Management, 17(4), 255-263. 
McNamara, K.E., \& Gibson, C. (2008). Environmental sustainability in practice? A macro-scale profile of tourist accommodation facilities in Australia's coastal zone. Journal of Sustainable Tourism, 16(1), 85-100.

Mair, J., \& Jago, L. (2010). The development of a conceptual model of greening in the business events tourism sector. Journal of Sustainable Tourism, 18(1), 77-94.

Marshall, R.S., Cordano, M., \& Silverman, M. (2005). Exploring individual and institutional drivers of proactive environmentalism in the US Wine Industry. Business Strategy and the Environment, 14(2), 92-109.

Meetings \& Events Australia, (2010). Green Events Checklist.

http://www.meetingsevents.com.au/downloads/Green\%20Policy\%20MEA\%2020082009.pdf. Viewed June, 2010.

Merrilees, B., Getz, D., \& O’Brien, D. (2005). Marketing stakeholder analysis: branding the Brisbane Goodwill Games. European Journal Marketing, 39(9/10), 1060-1077.

Park, E., \& Boo, S. (2010). An assessment of convention tourism's potential contribution to environmentally sustainable growth. Journal of Sustainable Tourism, 18(1), 95-113.

Patton, M.Q. (2002). Qualitative research and evaluation methods. 3rd ed. Thousand Oaks: Sage. 
Porter, M.E., \& Kramer, M.R. (2006). Strategy \& society: the link between competitive advantage and corporate social responsibility. Harvard Business Review, 84(12), 78-92.

Presbury, R., \& Edwards, D. (2005). Incorporating sustainability in meetings and event management education. International Journal of Event Management Education, 1(1), 30-45.

Revilla, G., Dodd, T.H., \& Hoover, L.C. (2001). Environmental tactics used by hotel companies in Mexico. International Journal of Hospitality \& Tourism Administration, 1(3/4), 111-127.

Sharma, S. (2000). Managerial interpretations and organizational context as predictors of corporate choice of environmental strategy. Academy of Management Journal, 43(4), 681-697.

Tilley, F. (1999). The gap between the environmental attitudes and the environmental behaviour of small firms. Business Strategy and the Environment, 8(4), 238-248.

Timsheva, O. (2001). Environmental legacy of the Olympic Games. Report on the International Olympic Academy’s Special Sessions and Seminars. http://ioa.org.gr/books/reports/2001/R2001_116.pdf 
Tzschentke, N., Kirk, D., \& Lynch, P.A. (2004). Reasons for going green in serviced accommodation establishments. International Journal of Contemporary Hospitality Management, 16(2), 116-124.

Wight, F. (1994). The greening of the hospitality industry: Economic and environmental good sense. In A.V. Seaton (Ed.), Tourism :the state of the art (pp. 665-672). John Wiley \& Sons, Chichester, UK.

Yin, R. (2004).The case study anthology. Thousand Oaks, California: Sage. 